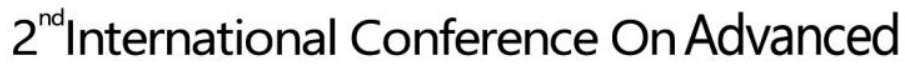 Research in HUMANITIES
}

\section{Opinion on Corporal Punishment in Schools among Youths in Sri Lanka}

\author{
Senevirathna K.C \\ Abhimana Community Development Association
}

\begin{abstract}
The program end violence against of Abhimana Sri Lanka (ACDA) was designed to improve the youth engagement to end violence against children in Sri Lanka. The questioner survey was done on perspectives on corporal punishment among youth who participating to "Yowunpuraya2019". The data shows that 43\% respondents were in age $20-25$ group and 64\% female respondents. The survey found that $78 \%$ been physically punished in school. The data shows that 3549 respondents mentioned that they were experienced beating from cane in school. As the impact of the corporal punishment most of the respondents were mentioned as lower selfconfidents (1401) and lower school attendance/dropouts of students (1377). The survey was intended to fund the perception of respondents on using corporal punishment as disciplinary method in school and $72 \%$ young respondent says that corporal punishment should not use as disciplinary action in school. The survey conclude that majority of young respondents experienced corporal punishment in their schooling ages and it was negatively impact for their future and they believe that corporal punishment should not use in school level as disciplinary action.
\end{abstract}

Keywords: corporal punishment, child protection, violence in school, youths 